\title{
Enhancement of Ionization Efficiency and Selective Enrichment of Phosphorylated Peptides from Complex Protein Mixtures Using a Reversible Poly-Histidine Tag
}

\author{
Pegah R. Jalili, Deepti Sharma, and Haydn L. Ball \\ Protein Chemistry Technology Center, University of Texas, Southwestern Medical Center, Dallas, Texas, USA
}

To improve the detection of phosphorylated peptides/proteins, a combination of optimized MS-based strategies were used involving chemical derivatization with a polyhistidine-tag (His-tag) and affinity enrichment of the resulting His-tag peptides on a nanoscale $\mathrm{Ni}^{2+}$-IMAC column. The phosphoserine and phosphothreonine peptides were derivatized using a one-pot $\beta$-elimination/Michael addition reaction with a reversible His-tag possessing a thiol-containing Cys residue. The His-tag peptides were enriched selectively by $\mathrm{Ni}^{2+}$-IMAC and released using either imidazole or cleavage with Factor Xa. This novel capture and enzyme-mediated release provided an additional element of selectivity and yielded phosphopeptide-specific modifications with enhanced MS ionization characteristics. The eluted peptides were mapped using MALDI-TOF MS and QTRAP ESI-MS/MS techniques. The results obtained for a model peptide and two tryptic protein digests show that the method is highly specific and allows selective enrichment of phosphorylated peptides at low concentrations of femtomoles per microliter. (J Am Soc Mass Spectrom 2007, 18, 1007-1017) (C) 2007 American Society for Mass Spectrometry

$\mathrm{O}$ ne of the best-known mechanisms for covalent modification, occurring in as many as one third of eukaryotic gene products, is protein phosphorylation, which regulates fundamental cellular events: cell division, cell growth, and cell differentiation. Because protein phosphorylation and other posttranslational modification cannot be predicted using gene sequence, several strategies have been used. The conventional approach for the detection of phosphorylation sites typically involves radioactive labeling of the phosphorylation site in growth media, followed by the isolation of ${ }^{32} \mathrm{P}$-labeled phosphorylated protein by immunoprecipitation or SDS-PAGE, enzymatic digestion, and Edman degradation [1, 2]. This approach, besides being a potential hazard, suffers from reduced sensitivity arising from the low abundance of phosphoprotein, limited amount of biological sample, inefficient incorporation of the ${ }^{32} \mathrm{P}$ label, and relatively poor sensitivity of automated Edman sequencing.

Mass spectrometry, which has long been used to identify proteins, is now the preferred technique for mapping post-translational modifications in proteins [3-6]. The analysis is rapid, sensitive, and does not require radiolabeling. Two soft ionization techniquesmatrix-assisted laser desorption/ionization mass spec-

Address reprint requests to Dr. H. L. Ball, Protein Chemistry Technology Center, UT Southwestern Medical Center, 6001 Forest Park Rd., Dallas, TX, 75390-8816. E-mail: haydn.ball@utsouthwestern.edu trometry (MALDI-MS) and electrospray ionization mass spectrometry (ESI-MS) - have been successful in detecting the phosphorylation sites in proteins $[7,8]$. However, in routine phosphopeptide mapping using MS, the following challenges appear. First, negative charges on phosphate groups result in suppression effects or a low efficiency of ionization. Second, the low stoichiometry and abundance of phosphorylated peptides in a mixture of peptides makes the exclusive characterization of phosphopeptides difficult. Third, the hydrophilic character of phosphopeptides may cause them to elute in the void volume in RP-HPLC. Finally, full sequence coverage by specific proteolysis of large phosphoproteins is difficult. These factors underscore the need for continued development of methods of enrichment before mass analysis [5, 8].

A common technique for enrichment of phosphorylated peptides and proteins from a complex mixture is immobilized metal ion affinity chromatography (IMAC) [9]. Phosphoproteins and peptides bind with specificity to immobilized metal ions, such as $\mathrm{Fe}^{3+}$, $\mathrm{Al}^{3+}$, and $\mathrm{Ga}^{3+}$ and usually elute at high $\mathrm{pH}$ values. However, the elution of phosphopeptides from IMAC resins can result in the loss of strongly bound phosphopeptides. Also, non-specific binding of negatively charged species may occur during the IMAC procedure [8-10]. In this case, a methylation step is essential to partially reduce the non-specific binding of highly negatively charged peptides to the resins [11]. Alkaline 
phosphatase treatment of the IMAC-enriched peptide, which causes the loss of a phosphate group and shifts the mass by $-80 \mathrm{Da}$, can further confirm the existence of phosphorylation sites and also enhances ionization efficiency [12]. The use of strong cation exchange chromatography before IMAC purification to further reduce the complexity of the sample and to yield a better coverage of monophosphorylated peptides has also been reported $[13,14]$. Recent studies have shown that nanocomposites such as titanium dioxide $\left(\mathrm{TiO}_{2}\right)$ and zirconium dioxide $\left(\mathrm{ZrO}_{2}\right)$ have a high loading capacity and specificity for phosphopeptides in large-scale analyses of protein phosphorylation in biological mixtures $[15,16]$. Two MS-based strategies-precursor ion scanning of $\mathrm{m} / \mathrm{z} 79$ in negative-ion mode and neutral loss scanning of $\mathrm{m} / \mathrm{z} 98$ in positive mode-have been used for selective detection of phosphorylated peptides within a complex mixture [17, 18].

Chemical derivatization strategies based on $\beta$ elimination of the phosphate moiety of phosphopeptides and Michael addition reaction with S- and $\mathrm{N}$-nucleophiles, such as ethanethiol, ethanedithiol, and ethylenediamine, are increasingly being described [19, 20]. In a recent study, Knight et al. [21] applied a phosphorylation-specific proteolysis technique, which converts the phosphorylation sites into lysine analogs using a $\beta$-elimination/Michael addition reaction. The resulting modified peptide can then be cleaved phosphospecifically by LysC endoprotease. Other chemical derivatization approaches have been developed based on the incorporation of biotin or fluorous affinity tags to aid the enrichment of phosphopeptides [22-24]. Although each of these methods has its own advantages and certain limitations, the development of new approaches for unambiguous, specific, and selective analysis of phosphoproteins to reduce suppression effects and enhance the detectability of phosphopeptides is still ongoing.

In the present work, a $\beta$-elimination/Michael addition reaction is used to replace the phosphate moiety of phosphoserine and phosphothreonine peptides with a His-tag. The thiol group on the side chain of Cys of the His-tag reacts with the dehydroalanine residue intermediate that is formed by the loss of phosphate moiety in alkaline conditions. His-tag peptides are enriched selectively by $\mathrm{Ni}^{2+}$-IMAC and mapped using $\mathrm{MS}$ and MS/MS techniques. Removal of the reversible His-tag ligand is achieved using Factor $\mathrm{Xa}$, which cleaves the His-tag peptide at the C-terminal side of Arg of the recognition sequence, thus liberating the immobilized peptide. Our novel enrichment strategy, in addition to the affinity purification of phosphopeptides from a complex mixture, improves the selectivity and specificity of analysis as a result of the specific recognition site of protease Factor Xa that is engineered into the His-tag linker. It is well known that the detailed analysis of MS/MS spectra of phosphopeptides with multiple phosphorylation sites using ion trap instruments remains challenging because of neutral loss of $98 \mathrm{Da}$ from each site. In our study, the final peptide used for MS analysis incorporates a Gly-Cys dipeptide linked through the thiol side chain of Cys at the site of phosphorylation. This modification significantly improves ionization efficiency because of the substitution of the negatively charged phosphate group, aids peptide fragmentation and thus facilitates identification of the precise sites of phosphorylation.

\section{Experimental}

Amino acids and solvents were purchased from Novabiochem (San Diego, CA, USA) or Fisher Scientific (Fair lawn, NJ, USA). $\alpha$-Casein (bovine) was purchased from Sigma-Aldrich/New Jersey Center for Biomaterials (Piscataway, NJ, USA). Inhibitor-1 (I-1) was provided by Dr. James Bibb (UT Southwestern Medical Center at Dallas, TX, USA). The materials used were barium hydroxide (Alfa Aesar, Ward Hill, MA, USA), gallium nitrate $\left[\mathrm{Ga}\left(\mathrm{NO}_{3}\right)_{3}\right]$, guanidinium $\mathrm{HCl}$, formic acid, trifluoroacetic acid (TFA), hydrogen peroxide (SigmaAldrich), Poros 20MC (PE Biosystems, Framingham, MA, USA), Factor Xa (Qiagen, Valencia, CA, USA), titanium oxide (ESPI, Ashland, OR, USA), and sequencing-grade modified trypsin, porcine (Promega, Madison, WI, USA). All matrices, $\alpha$-cyano-4-hydroxycinnamic acid (CHCA), 2,5-dihydroxybenzoic acid (DHB), and sinapinic acid were purchased from Agilent Technologies (Palo Alto, CA, USA).

\section{Synthesis of His-tag and Model Phosphopeptide}

The His-tag peptide $(\mathrm{m} / \mathrm{z}$ 1512.69, HHHHHHGIEGRGC) and model phosphopeptide [ $\mathrm{m} / \mathrm{z}$ 1732.75, RPHFPQFS $\left(\mathrm{PO}_{4}\right)$ YSASGTA], representing the C-terminal tryptic fragment of RAC- $\alpha$ serine/threonine-protein kinase (P47196) were synthesized on an automated ABI 433 peptide synthesizer (Applied Biosystems, Foster City, CA, USA) using optimized Fmoc/tBu chemistry on Fmoc-amide resin [26]. Crude peptides were purified by RP-HPLC (Waters, Milford, MA, USA) and then analyzed with MALDI-MS to confirm their identity. The purified fractions were pooled together and then lyophilized.

\section{His-tag Derivatization}

For the model phosphopeptide; the $\beta$-elimination/ Michael addition reaction was performed using $10 \mu \mathrm{L}$ of phosphopeptide (10 pmol), $10 \mu \mathrm{L}$ nucleophile $(1 \mathrm{nmol}), 5 \mu \mathrm{L}$ of $8 \mathrm{M}$ guanidine $\mathrm{HCl}, 5 \mu \mathrm{L}$ of $\mathrm{ACN}$, and $10 \mu \mathrm{L}$ of saturated barium hydroxide. Addition of these derivatizing chemical reagents further diluted the 10 pmol of phosphopeptide to a final concentration of $250 \mathrm{fmol} / \mu \mathrm{L}$. The reaction was allowed to proceed for $3 \mathrm{~h}$ at $45^{\circ} \mathrm{C}$. For $\alpha$-casein and I-1 protein samples, before derivatization, the protein mixture was subjected to performic acid oxidation by adding $50 \mu \mathrm{L}$ of $30 \%$ aqueous hydrogen peroxide: $95 \%$ formic acid (5:95 $\mathrm{vol} / \mathrm{vol}$ ) to $20 \mu \mathrm{g}$ of protein. The reaction mixture was 

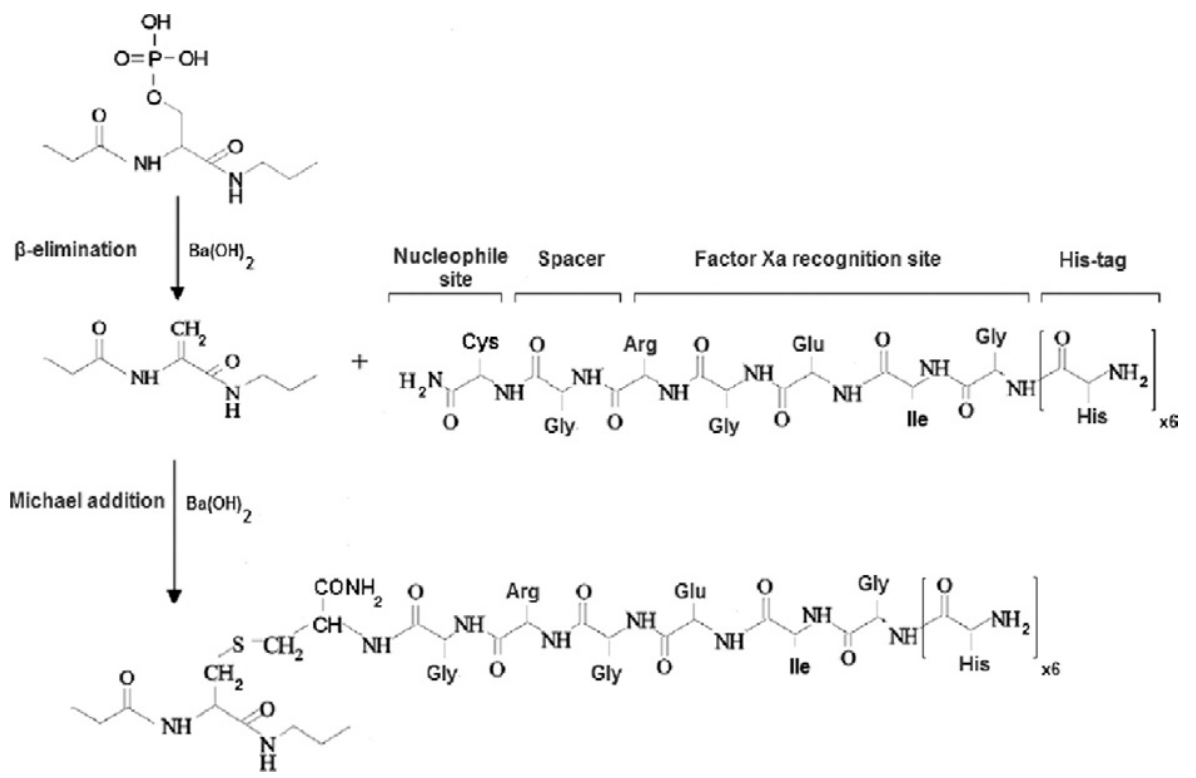

Scheme 1. $\beta$-Elimination and Michael addition reaction of phosphorylated peptide.

incubated overnight at $4{ }^{\circ} \mathrm{C}$ and dried in a centrifugal vacuum system. The dried sample was dissolved in $100 \mu \mathrm{L}$ of $100 \mathrm{mM}$ ammonium bicarbonate. Trypsin digestion of oxidized proteins was performed at $37^{\circ} \mathrm{C}$ overnight using the substrate/enzyme ratio of 100:1. The resulting mixture was diluted to $1 \mathrm{pmol} / \mu \mathrm{L}$ using $0.1 \%$ formic acid. The resulting solution $(10 \mu \mathrm{L})$ was used for derivatization. The derivatization of the resulting tryptic phosphorylated peptides followed the same procedure as described above, giving a final concentration of $250 \mathrm{fmol} / \mu \mathrm{L}$.

\section{$\mathrm{Ga}^{3+}$-IMAC Enrichment}

The method was performed according to the Millipore (Bedford, ${ }^{\circ}$ MA, ${ }^{\circ}$ USA) ${ }^{\circ}$ instructions ${ }^{\circ}$ for ${ }^{\circ}$ ZipTip $^{\otimes^{\circ}}$ (www. millipore.com).$^{\circ}$ Briefly, ${ }^{\circ}$ the ${ }^{\circ}$ tip $^{\circ}$ was $^{\circ}$ equilibrated ${ }^{\circ}$ by washing with $10 \mu \mathrm{L}$ of freshly prepared $0.1 \%$ acetic acid in $50 \% \mathrm{ACN}$ and primed using $10 \mu \mathrm{L} \mathrm{Ga}\left(\mathrm{NO}_{3}\right)_{3}$ in 10 $\mathrm{mM} \mathrm{HCl}$. Then the column was washed first with $10 \mu \mathrm{L}$ of Milli-Q water, followed by $10 \mu \mathrm{L}$ of $1 \%$ acetic acid containing $10 \%$ ACN. The samples were diluted with 10 $\mu \mathrm{L}$ of $0.1 \%$ acetic acid, applied to the top of the column, washed with $0.1 \%$ acetic acid, followed by $0.1 \%$ acetic acid in $10 \% \mathrm{ACN}$, and finally rinsed with Milli-Q water. The phosphopeptides were eluted from the column with $10 \mu \mathrm{L}$ of $0.3 \mathrm{M}$ ammonium hydroxide solution and the eluent acidified before C18 ZipTip desalting and MALDI-MS analysis.

\section{$\mathrm{TiO}_{2}$ Enrichment}

$\mathrm{TiO}_{2}$ powder was resuspended in $80 \% \mathrm{ACN}$ in $0.1 \%$ TFA and then packed into an Eppendorf gel-loader tip, which was blocked with a glass-wool frit. To optimize the binding of protein to the $\mathrm{TiO}_{2}$ micro-column, the $\mathrm{pH}$ values of the digested proteins were adjusted to 6.5. The resulting mixture was introduced into the $\mathrm{TiO}_{2}$ microcolumn and washed with $0.1 \%$ acetic acid followed by $50 \% \mathrm{ACN}$ in $0.1 \%$ acetic acid. The bound phosphopeptides were eluted with $0.5 \%$ ammonium hydroxide ( $\mathrm{pH}$ 9.5).

\section{His-tag/Ni ${ }^{2+}$-IMAC Enrichment}

The His-tag peptides were enriched using nanoscale $\mathrm{Ni}^{2+}$-IMAC. First, the Poros 20MC was prepared by suspending the resin in $20 \mathrm{mM} \mathrm{NiCl}_{2}$ in $10 \mathrm{mM} \mathrm{HCl}$. A nanoliter IMAC column was prepared by loading the IMAC resin into an Eppendorf gel-loader tip. The resin was washed with deionized water and the binding buffer ( $20 \mathrm{mM}$ Tris $\mathrm{HCl}, 5 \mathrm{mM}$ imidazole, $0.5 \mathrm{M} \mathrm{NaCl}$, $\mathrm{pH} 8$ ). A $5 \mu \mathrm{L}$ sample was diluted further with $5 \mu \mathrm{L}$ binding buffer and loaded on the top of the column. The bound His-tagged peptides were washed with a buffer containing $60 \mathrm{mM}$ Tris $\mathrm{HCl}, 5 \mathrm{mM}$ imidazole, $0.5 \mathrm{M}$ $\mathrm{NaCl}(\mathrm{pH} 8)$, and either eluted with solution containing $20 \mathrm{mM}$ Tris $\mathrm{HCl}, 0.5 \mathrm{M}$ imidazole, $0.5 \mathrm{M} \mathrm{NaCl}$ (pH 8) or treated with $10 \mu \mathrm{L}$ Factor Xa to liberate the immobilized peptide. (Note: His-tag/Factor Xa recognition site, HHHHHHGIEGR, remains attached to the IMAC.) The samples were desalted using Millipore C18 ZipTip (Millipore), washed with $10 \mu \mathrm{L}$ of $1 \%$ formic acid, and finally eluted with $50 \%$ ACN containing $1 \%$ formic acid. The eluent was analyzed on MALDI-MS and QTRAP ESI-MS/MS.

\section{Mass Spectrometry Analysis}

Mass spectrometry analyses were performed using a time-of-flight MALDI-MS (Micromass LR MALDI-TOF, Manchester, UK) and a 4000 QTRAP triple quadrupole/ 
linear ion trap (MDS Sciex, Ontario, Canada). The following settings were used for the QTRAP experiments: nano-ionspray voltage $+2000 \mathrm{~V}$, no heating of the source, curtain gas $20 \mathrm{psi}$, and declustering potential $+110 \mathrm{~V}$. Identification of phosphorylation sites and fragmentation was achieved by using MS product of Protein Prospector database. For MALDI-MS analysis, a $0.5 \mu \mathrm{L}$ aliquot of the sample was deposited onto the MALDI plate and then $0.5 \mu \mathrm{L}$ of the working matrix (DHB and sinapinic acid) solution was applied to the sample droplet. DHB was used for the lower mass scale 500 to $2000 \mathrm{Da}$ and sinapinic acid was used for identification of His-tag and phosphopeptides for mass range above $2000 \mathrm{Da}$. The sample-matrix droplet was allowed to air-dry at room temperature. Typically, spectra were obtained using a pulsed nitrogen UV laser (337 nm; $3 \mathrm{ns)} \mathrm{in} \mathrm{positive} \mathrm{linear} \mathrm{and} \mathrm{reflectron}$ mode; pulse voltage of $2800 \mathrm{mV}$; source voltage of $15,000 \mathrm{mV}$, using the MassLynx 4.0 Software (Waters Laboratory Informatics).

\section{Results and Discussion}

\section{Analytical Strategy}

Chemical modification-based on the alkali-mediated $\beta$-elimination of phosphoric acid from phosphoserine and phosphothreonine residues followed by Michael addition-was used for the enrichment and identification of phosphorylation sites. Several bases including barium hydroxide, sodium hydroxide, and ammonium bicarbonate based on previous studies were used for the $\beta$-elimination reaction. Although all of these bases generated $\beta$-elimination products, the results confirmed that barium hydroxide in ACN gave a higher yield for the attachment of the His-tag derivative to the double bond of the dehydroalanine intermediate. Many reports show that the thiol group is an efficient and fastreacting nucleophile for Michael addition reactions [19-22]. ${ }^{\circ}$ Therefore, $^{\circ}$ we $^{\circ}$ designed $^{\circ} \mathrm{a}^{\circ}$ His-tag $^{\circ}$ sequence consisting of three functional domains separated by Gly spacers. These were six histidines for binding to $\mathrm{Ni}^{2+}$ IMAC, a Factor Xa recognition site (Ile-Glu-Gly-Arg), and a sulfhydryl-containing Cys residue at the Cterminus of the peptide to act as nucleophile for attachment at the site of phosphorylation (Scheme 1).

Typically, the His-tag is introduced on the $\mathrm{N}$ - or C-termini and used as a means to affinity purify recombinant proteins from a bacterial expression system. In our research, we have adopted this approach for enrichment of phosphopeptides using $\mathrm{Ni}^{2+}$-IMAC, which binds the His-tag with micromolar affinity. The bound His-tag peptides were washed and eluted with $0.5 \mathrm{M}$ imidazole. Alternatively, the presence of the Factor Xa recognition site in the His-tag enables the bound peptides to be specifically detached from the column using Factor Xa protease. This protease recognizes the Ile-Glu-Gly-Arg sequence, cleaving the His-tag peptide and liberating the modified sequence peptide

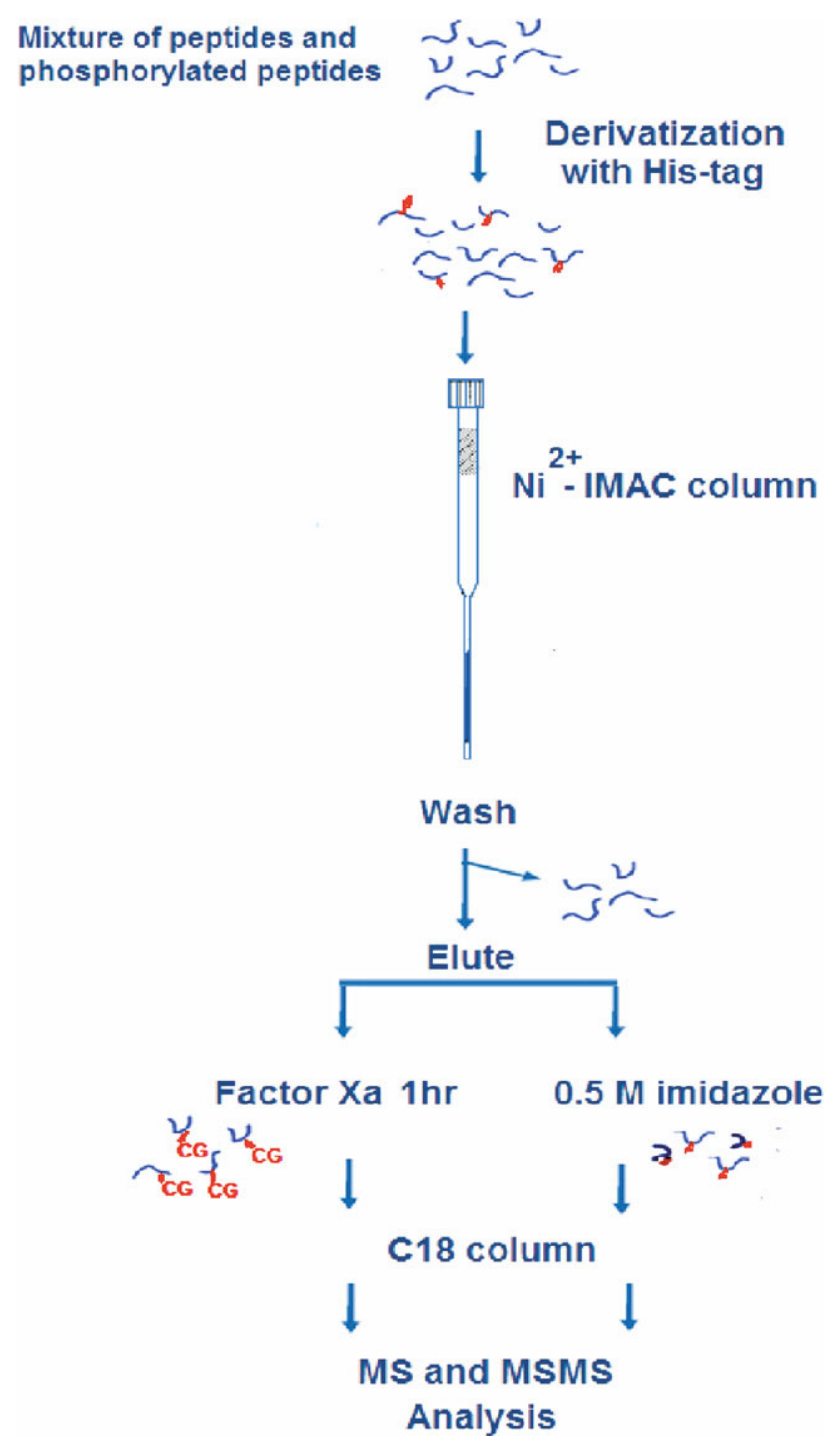

Scheme 2. His-tag enrichment strategy for the selective analysis of phosphopeptides.

with the Gly-Cys dipeptide attached at the site of phosphorylation. The His-tag/Factor Xa recognition site sequence remains attached to the IMAC resin (Scheme 2).

The specificity of Factor Xa adds a further dimension of selectivity to the analysis by leaving non-specific binders attached to the column. Furthermore, enrichment techniques that rely on binding of phosphopeptides to $\mathrm{Ga}^{3+}$ or $\mathrm{Fe}^{3+}$-IMAC often suffer from incomplete elution from the column using high $\mathrm{pH}$ buffers. Recently, a mixture of DHB and phosphoric acid has been shown to be an efficient eluent for $\mathrm{Fe}^{3+}$-IMAC and $\mathrm{TiO}_{2}$ columns $[27,29]$. ${ }^{\circ}$ Although ${ }^{\circ}$ this 9 mixture is ${ }^{\circ}$ suitable for MALDI-MS analysis, it is not compatible with ESI-MS, commonly used for phosphopeptide analysis. Factor Xa treatment is potentially a more reliable approach that may ultimately result in better recovery and thus sensitivity. The strategy was tested using the model peptide as well as phosphoprotein $\alpha$-casein. 
A model phosphopeptide
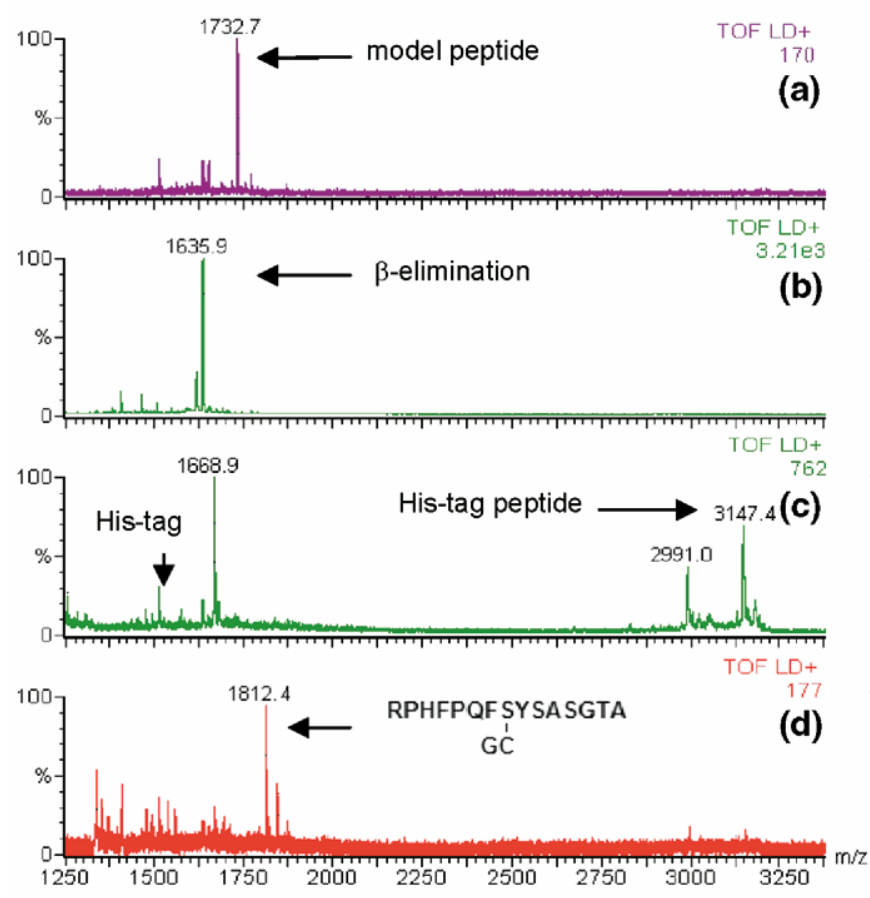

$\alpha$-Casein

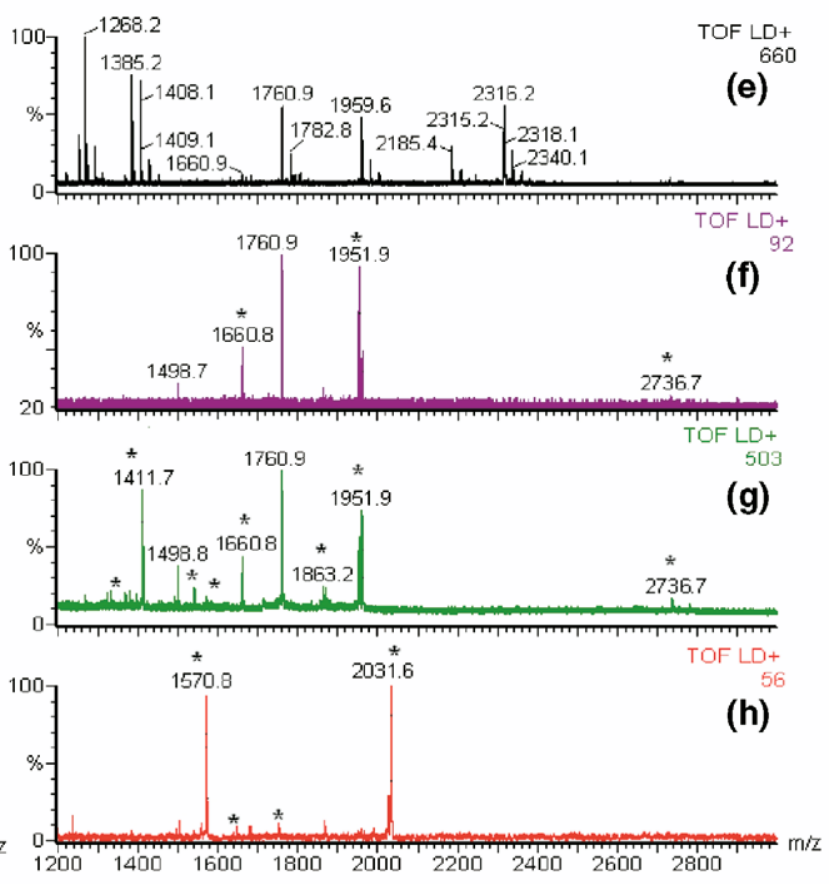

Figure 1. MALDI-MS spectra of (a) a model phosphopeptide, (b) after $\beta$-elimination, (c) after derivatization with His-tag (0.5 M imidazole treatment), and (d) His-tag peptide after IMAC purification (after Factor Xa treatment). MALDI-MS spectra of $\alpha$-casein (e) before derivatization and after (f) $\mathrm{Ga}^{3+}$-IMAC purification, (g) enrichment using $\mathrm{TiO}_{2}$, and (h) His-tag derivatization and IMAC purification after Factor Xa treatment. Phosphopeptides and modified peptides marked with *

Finally, we applied the methodology to investigate the phosphorylation status of I-1 (a substrate for cyclindependent kinase 5 and potent inhibitor of protein phosphatase 1). The experiments were performed at least three times to optimize the methodology and test the reproducibility. Qualitatively, the same modified peptides were recovered with each experiment under identical conditions and with similar yield.

\section{Phosphopeptide Enrichment of a Model Peptide}

To optimize the reaction conditions for derivatization, a model $^{\circ}$ phosphopeptide $^{\circ}\left(\right.$ Figure $^{\circ} 1$ 1a; $^{\circ} \mathrm{m} / \mathrm{z}$ 1732.79) ${ }^{\circ}$ and reversible His-tag, as nucleophile, were used. The MALDI-MS spectrum of the modified peptide shows the ${ }^{\circ}$ peak ${ }^{\circ}$ of $^{\circ} \mathrm{m} / \mathrm{z} 1635.92^{\circ}$ (Figure $\left.{ }^{\circ} 1 \mathrm{~b}\right)^{\circ}$ for ${ }^{\circ}$ the ${ }^{\circ}$ dihydroalanine intermediate, resulting from the loss of phosphate. The $^{\circ}$ peak $^{\circ} \mathrm{at}^{\circ} \mathrm{m} / \mathrm{z} 3147.43^{\circ}$ (Figure $\left.{ }^{\circ} 1 \mathrm{c}\right)^{\circ}$ corresponds $^{\circ}$ to ${ }^{\circ}$ the His-tag modified peptide. The His-tag peptide was enriched on the $\mathrm{Ni}^{2+}$-IMAC column and bound peptides were eluted with $0.5 \mathrm{M}$ imidazole. The eluent from IMAC was acidified with $5 \%$ acetic acid, desalted on a C18 ZipTip, and analyzed by MALDI and QTRAP-MS. All MALDI-MS data were obtained using linear ion mode because it improved and enhanced the signal generated by the phosphopeptides and His-tag derivatized $^{\circ}$ peptides. ${ }^{\circ}$ Holland $^{\circ} \mathrm{et}^{\circ}$ al. $^{\circ}[28]^{\circ}$ reported $^{\circ}$ that $^{\circ}$ peaks corresponding to post-translational modified peptides such as phosphorylation and glycosylation, which do not appear in the reflectron mode MALDI analysis, may appear in the linear mode. The peak of $\mathrm{m} / \mathrm{z} 3147.43$ (calculated $\mathrm{m} / \mathrm{z}$ 3147.46) was clear in the spectrum after enrichment. Treatment of His-tag peptides with Factor $\mathrm{Xa}$, which leaves a Gly-Cys dipeptide at the site of phosphorylation, resulted in a shift in molecular weight to a lower mass of $\mathrm{m} / \mathrm{z} 1812.39$ (calculated $\mathrm{m} / \mathrm{z} 1812.04$ ) (Figure ${ }^{\circ} 1 \mathrm{~d}$ ). ${ }^{\circ}$ Non-specific ${ }^{\circ}$ binders $^{\circ}$ such $^{\circ}$ as $^{\circ} \mathrm{m} / \mathrm{z} 1668.95$ remained attached to the IMAC column because these did not possess the Factor Xa recognition site and, as a result, ${ }^{\circ}$ are $^{\circ}$ absent ${ }^{\circ}$ in $^{\circ}$ the $^{\circ} \mathrm{MS}^{\circ}$ spectrum $^{\circ}$ (Figure ${ }^{\circ} 1 \mathrm{~d}$ ).

The data obtained show highly selective enrichment before MS analysis because of the combination of nanoscale IMAC, Factor Xa treatment, and the exclusive elimination of interference from other highly acidic peptides. However, MS/MS sequencing is required to unambiguously determine the phosphorylation sites.

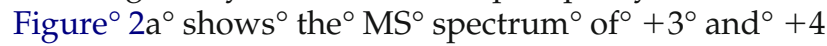
charged ions of His-tag peptide at $\mathrm{m} / \mathrm{z} 1050.31$ and 788.16, respectively. The peak of the His-tag ligand and its dimer are also present in this spectrum. After purification and treatment with Factor $\mathrm{Xa}$, the His-tagmodified peptide is cleaved at the carboxyl side of Arg, leaving Gly-Cys attached to the tryptic peptide. Consequently, the mass of the doubly charged ion shifts to $\mathrm{m} / \mathrm{z}$ 906.96 ${ }^{\circ}$ Figure $^{\circ} 2 \mathrm{~b}$ ) ${ }^{\circ}$ The $^{\circ}$ model $^{\circ}$ peptide $^{\circ}$ contains $^{\circ} \mathrm{a}$ phosphate group on Ser8 and the MS/MS data clearly 


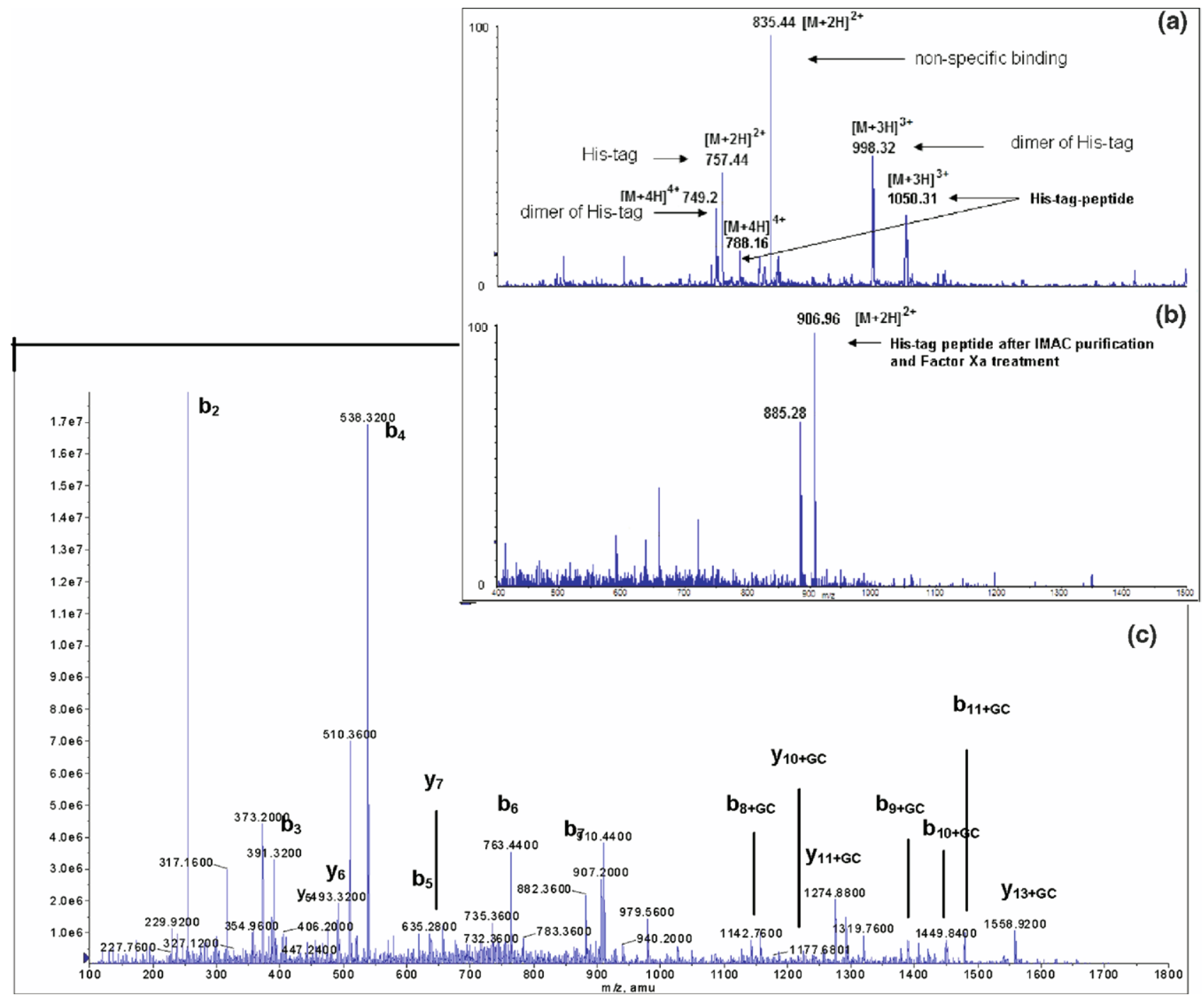

Figure 2. ESI-MS spectrum of (a) His-tag peptide before IMAC purification $\mathrm{m} / \mathrm{z} 1050.33$ for the $[\mathrm{M}+3 \mathrm{H}]^{3+}$ ion. (b) ESI-MS and (c) ESI-MS/MS spectra of Gly-Cys derivatized peptide $(\mathrm{m} / \mathrm{z}$ 906.96; $[\mathrm{M}+2 \mathrm{H}]^{2+}$ ion), after $\mathrm{Ni}^{2+}$-IMAC purification and Factor Xa treatment.

differentiated this site from the other Ser, Thr, and Tyr residues present in the sequence after its modification with ${ }^{\circ} \mathrm{Gly}^{-\mathrm{Cys}}{ }^{\circ}\left(\right.$ Figure $\left.^{\circ} 2 \mathrm{c}\right)$.

\section{Phosphopeptide Enrichment of $\alpha$-Casein}

To further evaluate this methodology we decided to use the His-tag for the chemical derivatization of $\alpha$-casein, a milk-derived protein, which possesses multiple phosphorylation sites. A previous study using mass spectrometry shows the presence of two variants with low sequence homology in the commercially available $\alpha$ casein. ${ }^{\circ} \mathrm{Carr}^{\circ} \mathrm{et}^{\circ}{ }^{\circ} .^{\circ}[17]^{\circ}$ detected $^{\circ}$ nine ${ }^{\circ}$ phosphorylation sites using precursor ion scanning on an ESI/MS instrument. However, they were not able to sequence all the phosphopeptides, especially those phosphopeptides with multiple phosphorylation sites attributed to the ionization suppression effects described previously [17]..$^{\circ}$ Larsen $^{\circ}$ et $^{\circ}$ al. $^{\circ}[29]^{\circ}$ detected $^{\circ}$ ten $^{\circ}$ phosphorylated peptides from $\alpha$-casein after $\mathrm{TiO}_{2}$ enrichment using MALDI-MS, including monophosphorylated and multiphosphorylated peptides. When samples were analyzed with ESI-MS, there was a bias towards the monophosphorylated species and several multiphosphorylated species, previously detected by MALDI-MS, were not observed. They attribute this finding to a lower amount of multiphosphorylated peptides compared to monophosphorylated peptides.

Phosphopeptides have traditionally been enriched using $\mathrm{Fe}^{3+}$ - and $\mathrm{Ga}^{3+}$-IMAC and, more recently, $\mathrm{TiO}_{2}$ bound to immobilized supports. To compare the selectivity and sensitivity of the His-tag strategy with these well-established methods, the same solution of $\alpha$-casein was enriched with either $\mathrm{Ga}^{3+}-\mathrm{IMAC}, \mathrm{TiO}_{2}$, or His-tag.

The imidodiacetic acid (IDA) and nitrotriacetic acid (NTA) resins commonly were used as stationary phase for metal ions in IMAC columns. Although NTA resin was superior to IDA resin, non-phosphorylated pep- 


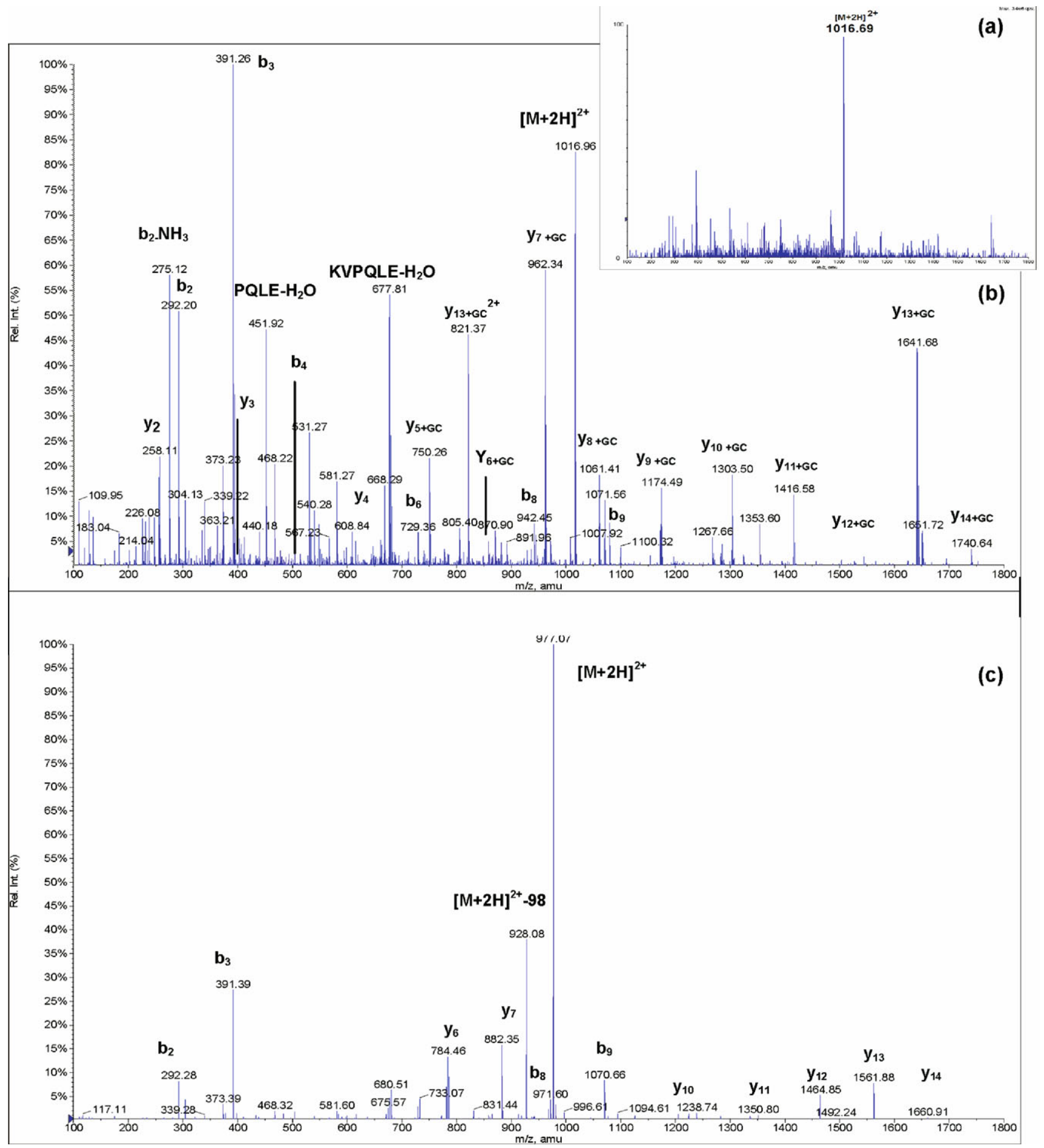

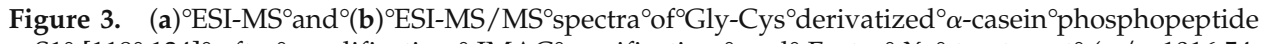
$\alpha$-S1 $1^{\circ}[119-134]^{\circ}$ after $^{\circ}$ modification, ${ }^{\circ}$ IMAC $^{\circ}$ purification, ${ }^{\circ}$ and ${ }^{\circ}$ Factor $^{\circ}$ Xa $^{\circ}$ treatment ${ }^{\circ}(\mathrm{m} / z$ 1016.54; $[\mathrm{M}+2 \mathrm{H}]^{2+}{ }^{\circ}$ ion $) .^{\circ}(\mathbf{c})^{\circ} \mathrm{ESI}^{-M S} / \mathrm{MS}^{\circ}$ spectrum ${ }^{\circ}$ of ${ }^{\circ}$ the ${ }^{\circ}$ precursor $^{\circ}$ phosphopeptide $^{\circ}$ YKVPQLEIVPNS*AEER before $^{\circ}$ His-tag $^{\circ}$ derivatization ${ }^{\circ}\left(\mathrm{m} / \mathrm{z}\right.$ 977.07; ${ }^{\circ}[\mathrm{M}+2 \mathrm{H}]^{2+}{ }^{\circ}$ ion $)$.

tides, ${ }^{\circ}$ including ${ }^{\circ}$ those $^{\circ}$ containing $^{\circ}$ multiple $^{\circ}$ acidic $^{\circ}$ residues, ${ }^{\circ}$ are ${ }^{\circ}$ frequently ${ }^{\circ}$ enriched ${ }^{\circ}$ by $^{\circ}$ this ${ }^{\circ}$ method..$^{\circ} \operatorname{In}^{\circ}$ our experiment, both $^{\circ} \mathrm{IMAC}^{\circ} \mathrm{ZipTip}^{\circ}$ with $^{\circ}{ }^{\circ} \mathrm{O}^{\circ} \mathrm{IDA}^{\circ}{ }^{\circ}{ }^{\circ} \sin ^{\circ}$ and NTA-Poros ${ }^{\circ} 0 \mathrm{MC}^{\circ}$ resins $^{\circ}$ were ${ }^{\circ}$ used $^{\circ}$ for ${ }^{\circ}$ the ${ }^{\circ}$ enrichment of $^{\circ}$ phosphopeptides ${ }^{\circ}$ and $^{\circ} \mathrm{His}^{\circ} \operatorname{tag}^{\circ}$ peptides. $^{\circ}$ Almost $^{\circ}$ the same ${ }^{\circ}$ result ${ }^{\circ}$ was $^{\circ}$ obtained $^{\circ}{ }^{\text {with }}{ }^{\circ}$ both ${ }^{\circ}$ resins. Three $^{\circ}$ phos-

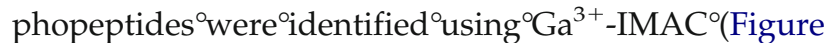
1f), ${ }^{\circ}$ eight ${ }^{\circ}$ phosphopeptides ${ }^{\circ}$ from ${ }^{\circ} \mathrm{TiO}_{2^{\circ}}$ enrichment ${ }^{\circ}$ (Figure $^{\circ} \mathrm{g}$ ), ${ }^{\circ}$ and $^{\circ}$ four $^{\circ}$ phosphopeptides $^{\circ}$ were $^{\circ}$ readily $^{\circ}$ detected ${ }^{\circ}$ using $^{\circ} \mathrm{His}^{\circ}$ tag $^{\circ}$ enrichment $/$ Factor $^{\circ} \mathrm{Xa}^{\circ}$ treatment (Figure $1 \mathrm{~h}$ ). The ${ }^{\circ}$ eight ${ }^{\circ}$ phosphopeptides ${ }^{\circ}$ identified ${ }^{\circ}$ sing $\mathrm{TiO}_{2^{\circ}}$ were $^{\circ} \alpha$-S2(141-151) ${ }^{\circ} \mathrm{at}^{\circ} \mathrm{m} / \mathrm{z} 1331.53^{\circ}$ (one ${ }^{\circ}$ phosphate 

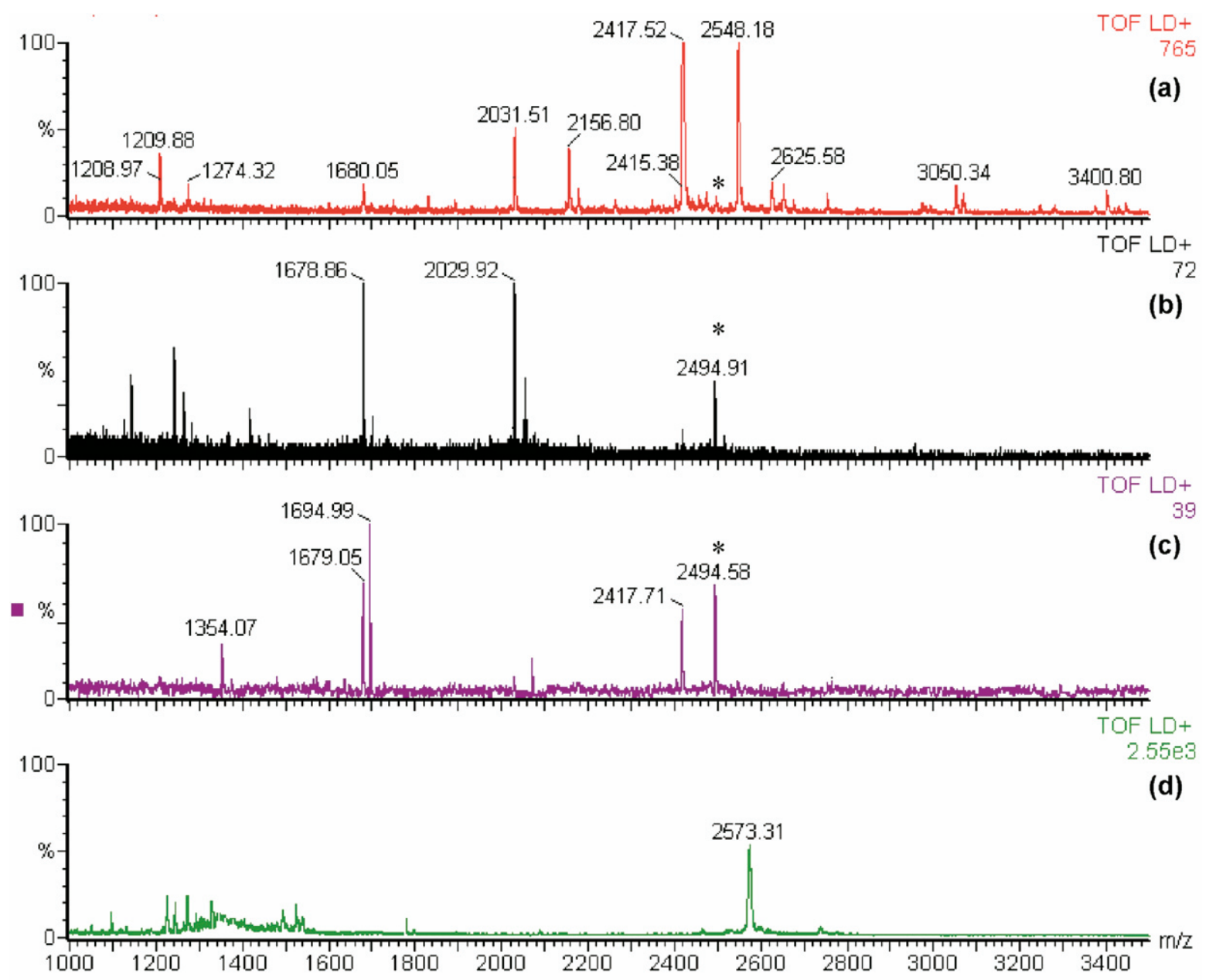

Figure 4. The MALDI-MS spectra of I-1 (a) before derivatization, (b) after $\mathrm{Ga}^{3+}$-IMAC purification, (c) $\mathrm{TiO}_{2}$ purification, and (d) after His-tag derivatization and IMAC purification after Factor Xa treatment.

group) and 1411.71 (two phosphate groups), $\alpha$-S2(153$165)$ at $m / z 1594.65$ (one phosphate group), $\alpha$-S2(141$152)$ at $m / z 1539.60$ (two phosphate groups), $\alpha$-S1(121$134)$ at $m / z 1660.80$ (one phosphate group), $\alpha$-S1(58-73) at $m / z 1863.27$ (one phosphate group, oxidized form), $\alpha$-S1(119-134) at $m / z 1951.95$ (one phosphate group), and $\alpha$-S1(74-94) at $m / z 2736.73$ (five phosphate groups, oxidized form).

In the present work, before chemical derivatization, the proteins were first subjected to performic acid treatment, which oxidizes cysteine, methionine, and tryptophan residues. This pretreatment blocks any undesirable side reactions that may occur between the Cys residue on the His-tag and Cys residues present in the $\alpha$-casein sequence. The peak of phosphorylated tryptic $\alpha$-casein peptide at $\mathrm{m} / \mathrm{z} 1951.91$ (calculated $\mathrm{m} / \mathrm{z}$ 1951.95) gains intensity at $\mathrm{m} / \mathrm{z} 3366.66$ (calculated $\mathrm{m} / \mathrm{z}$ 3366.67) after His-tag derivatization and IMAC purification (data not shown). The peak of the corresponding purified $^{\circ}$ derivatized ${ }^{\circ}$ peptide ${ }^{\circ}$ after ${ }^{\circ}$ Factor ${ }^{\circ}{ }^{\circ} a^{\circ}$ treatment $^{\circ}$ (Figure $\left.^{\circ} 1 \mathrm{~h}\right)^{\circ}$ appears $^{\circ}$ at $^{\circ} 2031.61^{\circ}$ (calculated ${ }^{\circ} \mathrm{m} / \mathrm{z}$ 2031.22). Similarly, other phosphopeptides with masses $\mathrm{m} / \mathrm{z}$
1411.71 (two phosphate groups), 1539.60 (two phosphate groups), and 1660.79 (one phosphate group) shift to $m / z 1570.85,1697.51$, and 1740.06 , respectively, as a result of the substitution of the phosphate group with the ${ }^{\circ}$ Gly-Cys ${ }^{\circ}$ dipeptide $^{\circ}\left(\right.$ Figure $^{\circ} 1 \mathrm{~h}$ )..$^{\circ}$ The $^{\circ}$ replacement ${ }^{\circ}$ of two phosphate groups on serine residues with the Gly-Cys dipeptides in EQLS(GC)TS(GC)EENSK tryptic peptide demonstrates that the method works effectively for multiple phosphorylation sites, including those in close proximity. The MALDI-MS spectrum after enrichment was significantly less complex than that obtained for the tryptic digest of $\alpha$-casein. Treatment of enriched immobilized His-tag peptides with Factor Xa provided further selectivity and specificity of the method and improved ionization efficiency arising from the substitution of phosphate group with Gly-Cys. It also removed the non-specific binders including the monomeric and dimeric forms of the His-tag ligand that might otherwise interfere with the MS analysis. Compared with the result obtained with $\mathrm{TiO}_{2}$ column where eight phosphopeptides were observed, the His-tag shows four phosphorylated peptides (two monophos- 


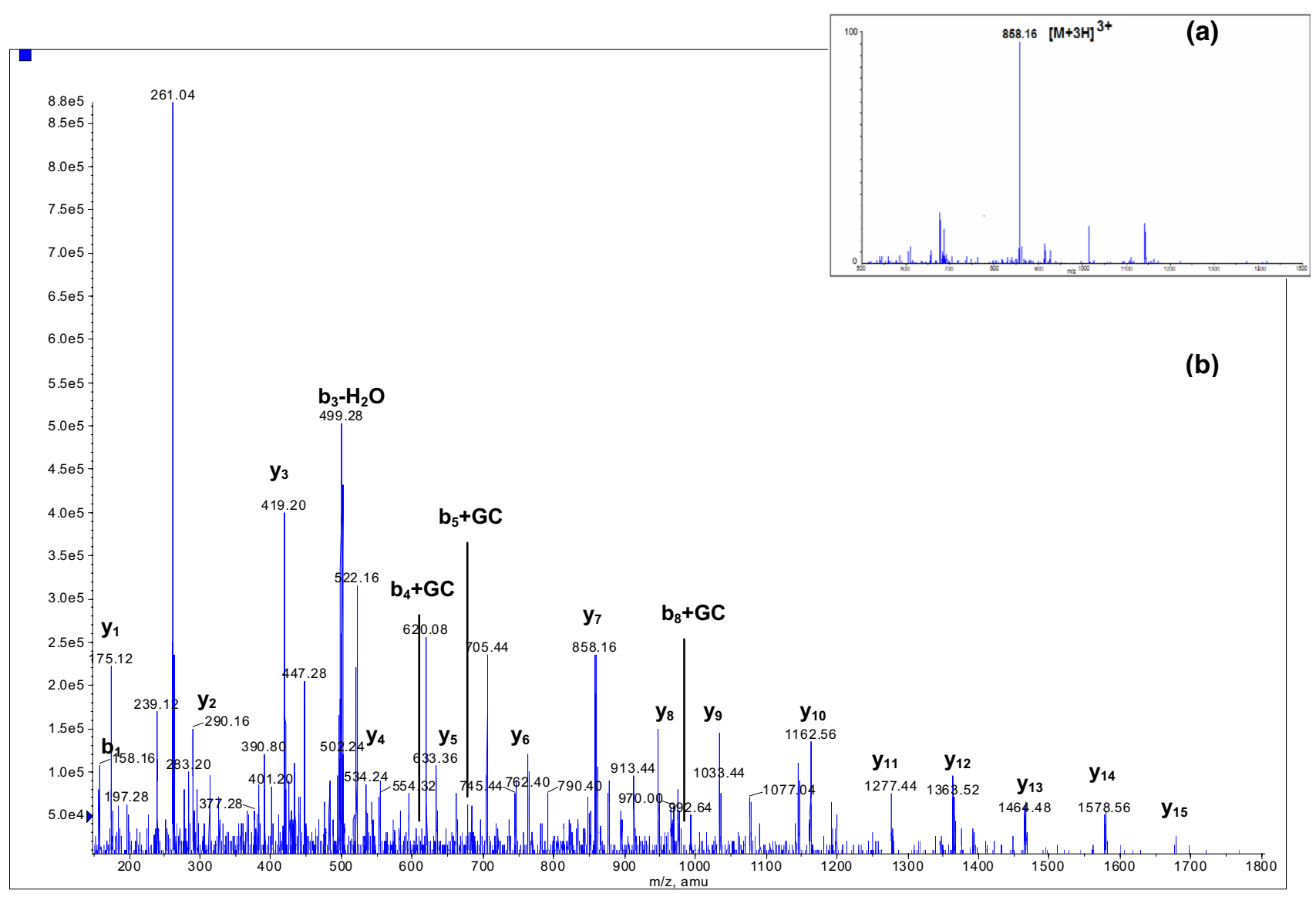

Figure 5. (a) ESI-MS and (b) ESI-MS/MS spectra of Gly-Cys derivatized I-1 phosphopeptide $(\mathrm{m} / \mathrm{z}$ 858.16; $[\mathrm{M}+3 \mathrm{H}]^{3+}$ ion) after modification, $\mathrm{Ni}^{2+}$-IMAC purification, and Factor Xa treatment. The corresponding sequence is RPT*PATLVLTSDQSSPEVDEDR.

phorylated ${ }^{\circ}$ and $^{\circ}{ }^{\circ} w 0^{\circ}$ diphosphorylated $^{\circ}$ peptides). ${ }^{\circ}$ The reason ${ }^{\circ}$ could ${ }^{\circ} b^{\circ}$ the ${ }^{\circ}$ low $^{\circ}$ abundance ${ }^{\circ}$ and $^{\circ}$ stoichiometry of ${ }^{\circ}$ the ${ }^{\circ}$ multiphosphorylated ${ }^{\circ}$ species. ${ }^{\circ}$ Data ${ }^{\circ}$ presented ${ }^{\circ}$ by Larsen $^{\circ} \mathrm{et}^{\circ} \mathrm{al} .{ }^{\circ}[29]^{\circ}$ support $^{\circ}$ this ${ }^{\circ}$ finding ${ }^{\circ}$ as $^{\circ}$ they ${ }^{\circ}$ observed $a^{\circ}$ significantly ${ }^{\circ}$ lower $^{\circ}$ sensitivity $^{\circ}$ for ${ }^{\circ}$ multi-phosphorylated ${ }^{\circ}$ peptides ${ }^{\circ}$ using $^{\circ}$ ESI-MS/MS.

The MS'(Figure $3 a)^{\circ}$ and 9 MS/MS'Figure $3 b$ ) ${ }^{\circ}$ spectra of $^{\circ}$ the $^{\circ}$ derivatized $^{\circ}$ peptide $^{\circ}$ were $^{\circ}$ obtained $^{\circ}$ using $^{\circ}$ a QTRAP $^{\circ} 4000 .^{\circ}$ Although ${ }^{\circ}$ the $^{\circ} y$ and $^{\circ} b$ ions $^{\circ}$ dominate the ${ }^{\circ}$ spectrum, ${ }^{\circ}$ the ${ }^{\circ}$ series ${ }^{\circ}$ of ${ }^{\circ} y$ ions ${ }^{\circ}{ }^{\circ}$ re $^{\circ}$ more $^{\circ}$ complete and $^{\circ}$ better $^{\circ}$ coverage $^{\circ}$ was $^{\circ}$ observed $^{\circ}$ over $^{\circ}$ the $^{\circ}$ high $\mathrm{m} / \mathrm{z}$ region. ${ }^{\circ}$ The $^{\circ}$ fragment $^{\circ}$ obtained $^{\circ}$ corresponds $^{\circ}$ to YKVPQLEIVPNSAEER $^{\circ}$ and $^{\circ}$ the ${ }^{\circ}$ mass $^{\circ}$ of $^{\circ} 160.04^{\circ} \mathrm{Da}$ was ${ }^{\circ}$ added $^{\circ}$ to $^{\circ}$ all $^{\circ}$ fragments $^{\circ}$ from $^{\circ} y_{5^{\circ}}$ to $^{\circ} y_{15},{ }^{\circ}$ which ${ }^{\circ}$ is attributed ${ }^{\circ} 0^{\circ}$ the ${ }^{\circ}$ addition ${ }^{\circ}$ of ${ }^{\circ} \mathrm{Gly}^{\circ} \mathrm{Cys}^{\circ} \mathrm{dipeptide}^{\circ}$ at ${ }^{\circ}$ the site $^{\circ}$ of $^{\circ}$ phosphorylation ${ }^{\circ}$ (Ser12).

To $^{\circ}$ demonstrate ${ }^{\circ}$ that ${ }^{\circ}$ the ${ }^{\circ}$ ionization ${ }^{\circ}$ characteristics $^{\circ}$ of the peptide improved, another ${ }^{\circ} \mathrm{MS} / \mathrm{MS}^{\circ}$ experiment ${ }^{\circ}$ was performed ${ }^{\circ}$ on $^{\circ}$ the ${ }^{\circ}$ unmodified ${ }^{\circ}$ phosphorylated ${ }^{\circ}$ precursor $^{\circ}$ peptide, ${ }^{\circ}$ using $^{\circ}$ the ${ }^{\circ}$ same $^{\circ}$ collision $^{\circ}$ energy $^{\circ}$ settings (Figure $3 \mathrm{c}$ ). ${ }^{\circ}$ In ${ }^{\circ}$ the ${ }^{\circ} \mathrm{MS} / \mathrm{MS}^{\circ}$ spectrum ${ }^{\circ}$ of ${ }^{\circ}$ the ${ }^{\circ}$ corresponding $^{\circ}$ phosphopeptide, ${ }^{\circ}$ the ${ }^{\circ}$ most $^{\circ}$ abundant ${ }^{\circ}$ and ${ }^{\circ}$ intense peak $^{\circ}$ was $^{\circ}$ that ${ }^{\circ}{ }^{\circ} f^{\circ}$ the ${ }^{\circ}$ doubly $^{\circ}$ charged $^{\circ}$ ion ${ }^{\circ}$ highlighting the ${ }^{\circ}$ difficulty ${ }^{\circ}$ of $^{\circ}{ }^{\circ}$ ionizing ${ }^{\circ}$ and ${ }^{\circ}$ fragmenting ${ }^{\circ}$ these ${ }^{\circ}$ phosphorylated ${ }^{\circ}$ species. ${ }^{\circ}{ }^{\circ}{ }^{\circ}$ omparison, ${ }^{\circ}$ the ${ }^{\circ}$ series $^{\circ}$ of $^{\circ} b$ and $^{\circ} y$ ions $^{\circ}$ are $^{\circ}$ far $^{\circ}$ more $^{\circ}$ intense ${ }^{\circ}$ in $^{\circ}$ the ${ }^{\circ}$ case $^{\circ}$ of ${ }^{\circ}$ the ${ }^{\circ}$ peptide modified ${ }^{\circ}$ with $^{\circ} \mathrm{Gly}-\mathrm{Cys} .{ }^{\circ} \mathrm{In}^{\circ}$ agreement ${ }^{\circ}$ with $^{\circ}$ the ${ }^{\circ}$ results, substitution ${ }^{\circ}$ of $^{\circ} a^{\circ}$ negatively ${ }^{\circ}$ charged $^{\circ}$ phosphate $^{\circ}$ for ${ }^{\circ}$ a protonated ${ }^{\circ}$ group $^{\circ}$ may improve ${ }^{\circ}$ ionization ${ }^{\circ}$ efficiency ${ }^{\circ}$ of the species ${ }^{\circ}$ of interest, ${ }^{\circ}$ augment ${ }^{\circ} \mathrm{CID}$ backbone ${ }^{\circ}$ fragmentation, ${ }^{\circ}$ and,${ }^{\circ}$ as $^{\circ}$ result, $^{\circ}$ facilitate ${ }^{\circ}$ phosphorylation ${ }^{\circ}$ site identification.

\section{Phosphopeptide Enrichment of I-1}

Inhibitory $^{\circ}$ subunit $^{\circ} 1^{\circ}(\mathrm{I}-1)^{\circ}$ is $^{\circ}$ derived $^{\circ}$ from $^{\circ}$ precursor protein ${ }^{\circ}$ phosphatase ${ }^{\circ}(\mathrm{PP} 1),{ }^{\circ}{ }^{\circ}$ which ${ }^{\circ} \mathrm{s}^{\circ} \mathrm{a}^{\circ} \mathrm{m}^{\circ} \mathrm{j}^{\circ} \mathrm{r}^{\circ}$ eukaryotic Ser $/ \mathrm{Thr}^{\circ}$ phosphatase $^{\circ} \mathrm{PP}^{\circ}{ }^{\circ}$ regulates $^{\circ}$ diverse $^{\circ}$ cellular processes ${ }^{\circ}$ such $^{\circ}{ }^{\circ}{ }^{\circ}$ glycogen $^{\circ}$ metabolism, ${ }^{\circ}$ cell ${ }^{\circ}$ division, muscle ${ }^{\circ}$ contraction, ${ }^{\circ}$ signal ${ }^{\circ}$ transduction, ${ }^{\circ}$ and ${ }^{\circ}$ neuronal functions. ${ }^{\circ} \mathrm{PP} 1^{\circ}$ has $^{\circ}$ targeting $^{\circ}$ and $^{\circ}$ inhibitory ${ }^{\circ}$ subunits. The ${ }^{\circ}$ targeting ${ }^{\circ}$ subunits ${ }^{\circ}$ confer $^{\circ}$ substrate ${ }^{\circ}$ specificity ${ }^{\circ}$ and inhibitory ${ }^{\circ}$ subunits $^{\circ}$ suppress $^{\circ}$ the $^{\circ}$ catalytic $^{\circ}$ activity $^{\circ}$ of PP1. $.^{\circ}-1^{\circ}$ is $^{\circ}$ phosphorylated ${ }^{\circ}$ on ${ }^{\circ} \mathrm{Thr} 35^{\circ}$ and ${ }^{\circ}$ Ser6 $67^{\circ}{ }^{\circ}{ }^{\circ}$ vivo. Once ${ }^{\circ}$ phosphorylated ${ }^{\circ}$ on ${ }^{\circ} \mathrm{Thr} 35^{\circ}, \mathrm{I}^{\circ} 1^{\circ}$ becomes $^{\circ} \mathrm{a}^{\circ}$ potent inhibitor ${ }^{\circ}$ of $^{\circ} \mathrm{PP}^{\circ}{ }^{\circ}$ [30]. ${ }^{\circ}$ The $^{\circ}$ MALDI-MS ${ }^{\circ}$ spectrum ${ }^{\circ}$ of tryptic ${ }^{\circ}$ digest $^{\circ}$ of ${ }^{\circ} \mathrm{I}-1^{\circ}$ before ${ }^{\circ}$ enrichment ${ }^{\circ}$ shows ${ }^{\circ}$ the ${ }^{\circ}$ peak of $^{\circ}$ the ${ }^{\circ}$ phosphopeptide $^{\circ}$ at $^{\circ} \mathrm{m} / z \quad 2494.58^{\circ}$ has $^{\circ}$ very $^{\circ}$ low intensity ${ }^{\circ}$ arising ${ }^{\circ}$ from $^{\circ}$ either $^{\circ}$ the $^{\circ}$ low $^{\circ}$ stoichiometry ${ }^{\circ}$ or the ${ }^{\circ}$ low $^{\circ}$ ionization ${ }^{\circ}$ efficiency ${ }^{\circ}{ }^{\circ}{ }^{\circ}$ the ${ }^{\circ} \mathrm{MS}^{\circ}$ (Figure 4 a). 
In our study, the phosphorylation site on Thr35 of I-1 was investigated using His-tag affinity enrichment and compared to $\mathrm{Ga}^{3+}$-IMAC and $\mathrm{TiO}_{2}$. Although, the latter techniques are definitely effective for the signal enhancement of low amounts of phosphopeptides from a complex mixture of tryptic peptides, the expected selectivity was not observed. The peaks of acidic peptides were also seen in the spectra but with lower intensity compared to the spectrum before enrichment. For instance, the peaks at $\mathrm{m} / z$ 1678.92 (ELQTMVEHHLGQQK) and 2030.07, which are the most abundant peaks in the spectrum of I-1, are also evident after enrichment using $\mathrm{Ga}^{3+}$-IMAC and $\mathrm{TiO}_{2}$ ( (Figure $4 \mathrm{~b}^{\circ}$ and $\left.{ }^{\circ} \mathrm{c}\right)$. ${ }^{\circ}$ However, these non-specific sequences are absent in spectra after Histag enrichment and the peak of Gly-Cys-modified peptide appears with high intensity at $\mathrm{m} / \mathrm{z} 2573.31$ (calculated ${ }^{\circ}$ mass $\left.^{\circ}{ }^{2573.82}\right)^{\circ}$ (Figure ${ }^{\circ} 4 \mathrm{~d}$ ). ${ }^{\circ}$ The $^{\circ}$ spectrum after enrichment and elution with Factor Xa is clear from other tryptic peptides and even highly acidic peptides, demonstrating the increased selectivity of the method.

Sequencing the triply charged ion of the Gly-Cysderivatized ${ }^{\circ}$ peptide $^{\circ}$ at $^{\circ} \mathrm{m} / \mathrm{z} 858.52^{\circ}\left(\text { Figure }^{\circ} 5 \mathrm{~b}\right)^{\circ}$ using ESI-MS/MS suggested that the sequence corresponded to RPT*PATLVLTSDQSSPEVDEDR, with Gly-Cys dipeptide providing a convenient marker for identifying the site of phosphorylation.

\section{Conclusion}

The combination of chemical derivatization with Histag and affinity enrichment using $\mathrm{Ni}^{2+}$-IMAC is a highly efficient approach for identification of low-level concentrations of phosphorylated peptides in a complex mixture of peptides. Although the number of identified phosphopeptides is higher using $\mathrm{TiO}_{2}$, the data presented here show that the treatment of enriched derivatized peptides with Factor Xa improves selectivity by eliminating a greater proportion of contaminating non-specific negatively charged species. Furthermore, substituting a phosphate group with a protonatable Gly-Cys dipeptide offers definite advantages over the phosphorylated precursor when analyzed by ESIMS/MS in positive mode. In addition, phosphatases, high $\mathrm{pH}$ conditions, and ionization in the ion trap MS instruments can cause loss of phosphate groups, resulting in lower sensitivity and increased difficulty identifying the phosphorylation sites. In this respect modification with the Gly-Cys dipeptide facilitates phosphorylation site identification. Results of this research confirm that this innovative method provides a reliable means of phosphopeptide mapping that offers advantages over published enrichment methods.

\section{References}

1. Aebersold, R.; Watts, J. D.; Morrison, H. D.; Bures, E. Determination of the Site of Tyrosine Phosphorylation at the Low Picomole Level by
Automated Solid-phase Sequence Analysis. Anal. Biochem. 1991, 199, 51-60.

2. Girault, J. A.; Hemmings, H. C. J.; Williams, K. R.; Nairn, A. C.; Greengard, P. Phosphorylation of DARPP-32, a Dopamine- and cAMPRegulated Phosphoprotein, by Casein Kinase II. J. Biol. Chem. 1989, 264, $21748-21759$.

3. Annan, R. S.; Carr, S. A. The Essential Role of Mass Spectrometry in Characterizing Protein Structure: Mapping Post-translational Modifications. J. Protein Chem. 1997, 16, 391-402.

4. Qin, J.; Chait, T. Identification and Characterization of Post-translational Modifications of Proteins by MALDI Ion Trap Mass Spectrometry. Anal. Chem. 1997, 69, 4002-4009.

5. Muszynska, G.; Dobrowolska, G.; Medin, A.; Ekamn, P.; Porath, J. O. Model Studies on Iron (III) Ion Affinity Chromatography II. Interaction of Immobilized Iron (III) Ions with Phosphorylated Amino Acids, Peptides and Proteins. J. Chromatogr. 1992, 604, 19-28.

6. Sparbier, K.; Koch, S.; Kessler, I.; Wenzel, T.; Kostrzewa, M. Selective Isolation of Glycoproteins and Glycopeptides for MALDI-TOF MS Detection Supported by Magnetic Particles. J. Biomol. Technol. 2005, 16, 407-413.

7. Dass, C. Principles and Practice of Biological Mass Spectrometry. John Wiley \& Sons: New York, 2001; pp 203-207.

8. Yi, Z.; Luo, M.; Mandarino, L. J.; Reyna, S. M.; Carroll, C. A.; Weintraub, S. T. Quantification of Phosphorylation of Insulin Receptor Substrate-1 by HPLC-ESI-MS/MS. J. Am. Soc. Mass Spectrom. 2006, 17, 562-567.

9. Nuwaysir, L. M.; Stults, J. T. Electrospray Ionization Mass Spectrometry of Phosphopeptides Isolated by On-line Immobilized Metal-ion Affinity Chromatography. J. Am. Soc. Mass Spectrom. 1993, 4, 662-669.

10. Posewitz, M.; Tempst, P. Immobilized Gallium (III) Affinity Chromatography of Phosphopeptides. Anal. Chem. 1999, 71, 2883-2892.

11. Brill, M. L.; Salomon, R. A.; Ficarro, B. S.; Mukherji, M.; Stettler-Gill, M. Peters, C. E. Robust Phosphoproteomic Profiling of Tyrosine Phosphorylation Sites from Human T Cells Using Immobilized Metal Affinity Chromatography and Tandem Mass Spectrometry. Anal. Chem. 2004, 76, 2763-2772.

12. Stensballe, A.; Andersen, S.; Jensen, O. N. Characterization of Phosphoproteins from Electrophoretic Gels by Nanoscale Fe (III) Affinity Chromatography with Off-line Mass Spectrometry Analysis. Proteomics 2001, 1, 207-222.

13. Trinidad, C. J.; Specht, G. C.; Thalhammer, A.; Schoepfer, R.; Burlingame, L. A. Comprehensive Identification of Phosphorylation Sites in Post-synaptic Density Preparations. Mol. Cell. Proteomics 2006, 5, 914 922.

14. Lim, K. B.; Kassel, D. B. Phosphopeptides Enrichment Using On-line Two-dimensional Strong Cation Exchange Followed by Reversed-phase Liquid Chromatography/Mass Spectrometry. Anal. Biochem. 2006, 354, 213-219.

15. Shih-Shin, L.; Makamba, H.; Shang-Yu, H.; Shu-Hui, C. Nano-titanium Dioxide Composites for the Enrichment of Phosphopeptides. J. Chromatogr. A 2006, 1116, 38-45.

16. Kyong, K. H.; Hakansson, K. Selective Zirconium Dioxide-based Enrichment of Phosphorylated Peptides for Mass Spectrometric Analysis. Anal. Chem. 2006, 78, 1743-1749.

17. Carr, A. S.; Huddleston, J. M.; Annan, S. R. Selective Detection and Sequencing of Phosphopeptides at the Femtomole Level by Mass Spectrometry. Anal. Biochem. 1996, 239, 180-192.

18. Bateman, R. H.; Carruthers, R.; Hoyes, J. B.; Jones, C.; Langridge, J. I. Millar, A.; Vissers, J. P. A Novel Precursor Ion Discovery Method on a Hybrid Quadrupole Orthogonal Acceleration Time-of-Flight (Q-TOF) Mass Spectrometer for Studying Protein Phosphorylation. J. Am. Soc. Mass Spectrom. 2002, 13, 792-803.

19. Klemm, C.; Schröder, S.; Glückmann, M.; Beyermann, M.; Krause, E. Derivatization of Phosphorylated Peptides with S- and N-Nucleophiles for Enhanced Ionization Efficiency in Matrix-assisted Laser Desorption/Ionization Mass Spectrometry. Rapid Commun. Mass Spectrom. 2004, 18, 2697-2705.

20. Molloy, M. P.; Andrews, P. C. Phosphopeptide Derivatization Signatures to Identify Serine and Threonine Phosphorylated Peptides by Mass Spectrometry. Anal. Chem. 2001, 73, 5387-5394.

21. Knight, Z. A.; Schilling, B.; Row, R. H.; Kenski, D. M.; Gibson, B. W.; Shokat, K. M. Phosphospecific Proteolysis for Mapping Sites of Protein Phosphorylation. Nat. Biotechnol. 2003, 21, 1047-1054.

22. Oda, Y.; Nagasu, T.; Chait, B. T. Enrichment Analysis of Phosphorylated Proteins as a Tool for Probing the Phosphoproteome. Nat. Biotechnol. 2001, 19, 379-382.

23. Brittain, S. M.; Ficarro, S. B.; Brock, A.; Peters, E. C. Enrichment and Analysis of Peptide Subsets Using Fluorous Affinity Tags and Mass Spectrometry. Nat. Biotechnol. 2005, 23, 463-468.

24. Adamczyk, M.; Gebler, J. C.; Wu, J. Selective Analysis of Phosphopeptides within a Protein Mixture by Chemical Modification, Reversible Biotinylation and Mass Spectrometry. Rapid Commun. Mass Spectrom. 2001, 15, 1481-1488.

25. Vosseller, K.; Hansen, K. C.; Chalkley, R. J.; Trinidad, J. C.; Wells, L. Hart, G. W.; Burlingame, A. L. Quantitative Analysis of Both Protein Expression and Serine/Threonine Post-translational Modifications through Stable Isotope Labeling with Dithiothreitol. Proteomics 2005, 5, 388-398. 
26. Kang, J.; Low, W.; Norberg, T.; Meisenhelder, J.; Hansson, K.; Stenflo, J.; Zhou, G. P.; Imperial, J.; Olivera, B. M.; Rigby, A. C.; Craig, A. G. Total Chemical Synthesis and NMR Characterization of the Glycopeptide tx5a, a Heavily Post-translationally Modified Conotoxin, Reveals That the Glycan Structure Is Alpha-D-Gal- $(1 \rightarrow 3)$-alpha-D-GalNAc. Eur. J. Biochem. 2004, 271, 4939-4949.

27. Stensballe, A.; Jensen, O. N. Phosphoric Acid Enhances the Performance of Fe(III) Affinity Chromatography and Matrix-assisted Laser Desorption/Ionization Tandem Mass Spectrometry for Recovery, Detection and Sequencing of Phosphopeptides. Rapid Commun. Mass Spectrom. 2004, 18, 1721-1730.
28. Holland, W. J.; Deeth, C. H.; Alewood, F. P. Proteomic Analysis of $\kappa$-Casein Micro-heterogeneity. Proteomics 2004, 4, 3743-3752.

29. Larsen, M. R; Thingholm, T. E.; Jensen, O. N.; Roepstorff, P.; Jorgensen, T. J. Highly Selective Enrichment of Phosphorylated Peptides from Peptide Mixtures Using Titanium Dioxide Microcolumns. Mol. Cell. Proteomics 2005, 4, 873-886.

30. Sahin, B.; Kansy, J. W.; Nairn, A. C. Spychala, J.; Ealick, S. E. Fienberg, A. A.; Greene, R. W.; Bibb, J. A. Molecular Characterization of Recombinant Mouse Adenosine Kinase and Evaluation as a Target for Protein Phosphorylation. Eur. J. Biochem. 2004, 271 3547-3555. 